\title{
Entrepreneurial Activities in Postsecondary Education
}

\section{STEVE O. MICHAEL * \& EWARD A. HOLDAWAY ${ }^{\dagger}$}

\begin{abstract}
Postsecondary education in western countries has experienced four major phases in this century. An elite phase persisted until about 1945 when a reconstructionist phase emerged, reflecting a more democratic approach. The third phase of reductions in funding and support characterized the 1980s. Inadequate revenues to meet rising costs, government measures, and institutional efforts to become more market-oriented can be viewed as complementary developments which were largely responsible for the current entrepreneurial phase.

Entrepreneurial aspects of postsecondary education include the extent to which users should pay, the balance between market-related and purely academic activities, the relative emphases upon basic and applied research, fundraising, and greater involvement of institutions and individuals in obtaining patents, licences, and cooperating with sizeable companies. A more entrepreneurial emphasis has implications for postsecondary administrators, especially in the matters of budget allocations, the need for more training of administrators, and increased attention to student needs. While a greater market orientation is warranted, care must be exercised to ensure that the academic mandate remains paramount.
\end{abstract}

\section{Résumé}

Dans les pays occidentaux, l'éducation post-secondaire a passé par quatre phases importantes de développement duranat ce siècle. Une phase plutôt élitiste a persistée jusque vers 1945 alors que faisait surface une phase reconstructioniste ayant un caractère plus démocratique. La troisième phase pendant les années 1980 a été caractérisée par une réduction de ressources financières et du soutien aux institutions. L'insuffisance des revenus face aux coûts croissants, les mesures et les efforts des institutions pour devenir plus centrées sur des exigences de marché, peuvent être considérés comme des développements complémentaires en grande partie responsables de la phase entrepreneuriale actuelle.

\footnotetext{
* Assistant Professor at the Bristol Bay Campus of the University of Alaska.

${ }^{\dagger}$ Professor of Educational Administration at the University of Alberta.
} 
En ce qui a trait à l'éducation postsecondaire, les questions soulevées par le développement de l'entrepreneurship ont porté sur la récupération des coûts directs et indirects de la recherche, l'équilibre entre la recherche pure et appliquée, la levée de fonds, la participation croissante des individus et des institutions à l'obtention de brevets d'invention et de permis, et enfin, sur la coopération avec les grandes sociétés. reliées au marché et les activités purement académiques, la cueillette de fonds, et la participation croissante des individus et des institutions à l'obtention de brevets d'invention et de permis, et enfin, sur la coopération avec les grandes sociétés. Cette orientation plus entrepreneuriale force les administrateurs et administratrices dans les établissements postsecondaires à ré-examiner les allocations budgétaires, la formation même des gestionnaires, et surtout les besoins de formation des étudiants et étudiantes. Bien qu'une orientation plus centrée sur le marché soit souhaitable, il faut s'assurer que la mission académique des institutions demeure de la plus haute importance.

\section{Entrepreneurial Activities in Postsecondary Education}

Across Canada, and in many other countries, public postsecondary educational institutions are engaged in entrepreneurial activities to a greater extent than ever before. Both advocates and opponents of entrepreneurship exist, but the issues and implications have not been examined as critically as they deserve. The thesis of this paper is that postsecondary institutions are currently becoming more entrepreneurial as a result of three complementary developments involving

underfunding, government influence, and institutional initiatives. Consequently, definitions and meanings of entrepreneurship and marketing in postsecondary education are addressed, some aspects of the history of institutions of higher education are reviewed, three complementary developments are described, and the issues and implications of entrepreneurialism for the administration of postsecondary education are examined.

\section{Definitions and Meanings}

The word "entrepreneur" generally refers either to a planner or manager of an enterprise or to someone who assumes the risk of an enterprise. In economics, an entrepreneur is one of the four factors of production, the others being land, labour, and capital. An entrepreneur is the catalyst, the agent of change and economic progress, and the one who reaps the loss or profit of an enterprise. An "entrepreneurial activity" therefore refers to the act of planning, setting up, 
and/or managing a business enterprise. In postsecondary education, the terms have several different meanings. An "entrepreneurial initiative," for example, may be used to describe the coming together of a postsecondary institution and an industry for either research or cooperative education purposes. "Entrepreneurial higher education" may be used to describe a market-system of higher education, in which the administrators of a postsecondary institution think and act similarly to those of a business enterprise. Also, "entrepreneurial efforts" may be used to describe activities engaged in by a postsecondary institution to generate funds, for example, renting out an underutilised facility, or buying and selling investments, or selling intellectual property. In this regard, Emery (1987) noted that:

the most promising entrepreneurial avenues available to the tertiary educational sector appear to be: greater co-operation with commerce and industry; the development of private, fee-paying universities and colleges; and the provision of extension education services in the form of corporate consultancies and contracts, mainly as export commodities (p. 84).

In this paper, "entrepreneurial higher education" implies all the conditions previously described, but especially the structuring and administering of a postsecondary institution to reflect a market orientation and less dependence upon government funding.

Marketing activities have increased both quantitatively and qualitatively in postsecondary institutions as these institutions have become more entrepreneurial. Since the word "marketing" means different things to different people, it requires some elaboration. In this paper, marketing is viewed as both a process and philosophy. As a process, marketing involves the sequential phases of identification of needs, development of appropriate programs, delivery of these programs, feedback about program effectiveness, and modification of existing programs. As a philosophy, marketing requires that institutional activities be planned, coordinated, and executed in a manner that optimally benefits the society, the clients, the relevant publics, and the institution. Marketing serves as an exchange-facilitating function between an entrepreneurial organization and its constituencies. The correct use of marketing, in the view of Kotler and Fox (1985), enables an organization to sense, serve, and satisfy targeted constituencies in a way that is beneficial to both the organization and its target constituencies. 


\section{Antecedents}

In an attempt to map and analyze the historical development of postsecondary education in western countries, four major overlapping phases can be identified and given the following arbitrary names-"elitism," "reconstructionism," "reductionism," and "entrepreneurialism." The first phase, elitism, occurred when higher education was reserved for the privileged few. As observed in the Bulletin of the Canadian Society for the Study of Higher Education (1991), "the first universities, which began in 11 th-century Europe, were like private clubs for privileged members" (p. 2). The second phase, reconstructionism, occurred when universal access to education was introduced as a result of perceived benefits of education to society. Education after the Second World War was essentially reconstructionist. The administration of educational systems and institutions reflected the need to rebuild nations. Governments were enthusiastic about funding education, which was perceived as an instrument to achieve development. Emphasis was placed on universal access and on central planning. Democratisation of education was based on many positive assumptions, including the following: (a) the number of graduates from higher educational institutions is positively correlated with the gross national product; (b) education possesses a capacity to develop a stronger moral sense; and (c) education ensures equal opportunity for all citizens (Tomlison, 1989; Burrup \& Brimley, 1982). The second phase was characterized by hope and expectations; it was a period when education enjoyed generous financial support from governments.

The third phase, reductionism, occurred when resources and government financial support declined. Reductionism is used broadly to describe a situation where operating grants either decline or do not increase sufficiently to meet increased costs, and decreases occur in student enrolment (in some places), political support, and/or other resources. While some agreement is evident that benefit has resulted from reconstructionalist postsecondary educational activities, as hoped for after the Second World War, there is no agreement as to how much financial investment produces a particular level of education. Consequently, this important question remains unanswered: At what point will additional funding produce zero return in education? Ribich (1970) pointed out that "increased public spending on education is hardly the most direct way to attack the problem of poverty" (p. 207). He argued that the extra funding must result in additional learning, that the additional learning must lead to an increased capacity to produce, and that this capacity must lift the individual out of poverty. Within this period of reductionism, which is still present, several 
measures have been adopted by various governments in an attempt to achieve their goals. Some of these include measures to increase accountability, zerobased budgeting, system rationalisation, and various measures to enhance efficiency. Apprehension among students and staff and lowering of morale have been common outcomes.

The fourth phase, entrepreneurialism, began when the entrepreneurial spirit was injected into educational systems. This phase incorporates many activities resulting from funding difficulties, government intervention, and the recognition that universities can undertake revenue-generating initiatives to a much greater extent than they have previously. These matters are addressed in the following sections.

\section{Revenue and Costs}

The need for fiscal restraint has forced the governments of many nations to make proportional reductions in their spending on traditional public services. Decore and Pannu (1989, p. 150) noted that, since the mid-1970s, Canada, the United States, the United Kingdom, Germany, Sweden, the USSR, and Japan experienced a continual decline in educational spending relative to their gross national products. For Canada, Gregor (1990) noted that the resources committed to postsecondary education as a percentage of GNP decreased from $2.5 \%$ in 1970 to $1.9 \%$ in $1987-88$ : in this latter year, $71 \%$ was provided by the provinces, $12 \%$ directly by the federal government, $9 \%$ from student fees, and $8 \%$ from other sources (p. 960). A provincial example is provided by Alberta Advanced Education (1989b) which has as one of its goals and priorities for the 1990-2000 AD decade the development of "a framework which will encourage and support a reduced reliance on provincial government revenues" (p. 2).

The European funding situation was assessed in the following three sections of Resolution 945 of the Parliamentary Assembly of the Council of Europe (1990):

The Assembly...

3. Notes that the problems of financing universities and other institutions of higher education concern all member States, despite the considerable diversity in the situation and structure of higher education in Europe on the one hand and the heterogeneity of levels of economic development on the other;

4. Observes that, in most member States, the lack of sufficient financial means is mainly due to a rise in the number of students enrolled, to the major increase in the costs of education and research, and to 
stagnation in public funding;

5. Regrets the negative effects of this situation on the quality of higher education, on research (the results of which are rarely readily marketable), on the independence and autonomy of institutions of higher education and lastly on co-operation between them in Europe (as a result of the increasing disparity in their resources). (p. 13)

Further, the political support for a substantial increase in educational budgets, which would probably increase taxes, is presently at a low level in many nations. Education is forced to compete with other areas, such as health care, social programs, defence, and municipal services, for its share of government funds. The difficulty of identifying any clear cause-and-effect relationships in educational investments has not helped politicians who, more often than not, are interested in simple and direct answers and must provide tangible justifications for their presence in office. In many places, governments have instituted measures that have radical consequences for educational finance and for college and university administration.

Gregor (1990), however, noted that the perceived tendency of Canadian provincial governments to underfund the postsecondary system "does not reflect the public will" and that "opinion polls have indicated an overwhelming majority ... in favour of increased postsecondary spending, and a substantial majority acknowledging the importance of postsecondary education to the community and the individual citizen" (p. 961). Gregor added that the raising of fees also was supported. A 1991 poll, conducted by the Angus Reid Group (Tausig, 1991), provided further evidence of positive public attitudes. This poll showed that 60 percent considered that "funding from the federal government should increase" and 69 percent agreed "that university education is 'very important' to Canada's economic competitiveness and social development” (p. 48).

While postsecondary institutions continue to be affected by inadequate government grants, the costs of running these institutions are increasing rapidly for the following three reasons: these institutions are not insulated from the general inflation in the environment; the number of students demanding higher education is rising; and centres of excellence are expensive to operate.

In summary, the level of government funding needed to support postsecondary institutions has declined in many countries. This is a concern to both governments and the institutions. While government grants continue to decline in relative terms and in some cases in absolute terms, student enrolment continues to grow. The costs of running modern libraries, installing modern 
laboratories, and hiring high-quality faculty have put extraordinary pressures on administrators of higher education. Consequently, increasing fees (which are usually under government control), engaging in more entrepreneurial activities, and shifting of costs through privatization of some functions, are perceived to be popular measures to improve the financial picture.

\section{Government Intervention}

In several countries, some realignment of postsecondary operations and offerings has occurred as a result of redirection of government funding. This is closely related to the extent to which postsecondary decision-making is decentralised. In a fully decentralised system, decisions about budgets, operations, administration, admissions, and curricula would be made locally. Such systems are rare, even in the private sector, as the high proportion of funding which comes from government and the need for coordination among institutions both require that governments or their agents exercise substantial influence. As Carter (1980) has stated, "society invests considerable resources in higher education, and evidently expects some benefit to follow" (p. 21).

For Canada, Axelrod (1986) provided this information:

In the fall of 1981, Ottawa promised to reduce dramatically its support of higher education through the Established Programs Financing arrangement and to redirect its funds toward university programs and research designed to serve the country's economic needs. In every region, provincial governments took initial steps to control the growth of academic programs, to avoid "duplication" of facilities, and to encourage universities to "rationalize" their development in accordance with economic demand. (p. 56)

Throughout the late 1980s, Alberta Advanced Education (1989a) embarked upon rationalisation of the postsecondary education system; its Guidelines for System Development (1989) stated that "government has expressed its intention to rationalise the system, that is, to ensure that unnecessary duplication is minimised, that program gaps are addressed, [and] that the benefits of specialization are realized" (p. 1). These Guidelines emphasised the need for these institutions to strive for efficiency and effectiveness. A few months after the publication of this document, Alberta Advanced Education (1989b) released a statement which outlined its goals and priorities for postsecondary education and expressed its intentions to encourage institutions to reduce their reliance on provincial government revenues. While the purpose of rationalisation was to reduce cost; diversification of sources of funding was expected to supplement inadequate 
government funding.

Similar sentiments were expressed in the 1980s in the United Kingdom. A 1987 government White Paper entitled Higher Education: Meeting the Challenge (cited in Maclure, 1988), included these statements:

Higher education has a crucial role in helping the nation to meet the economic and social challenges of the final decade of this century and beyond. . . . Higher education should:

- serve the country more effectively

- pursue basic scientific research and scholarship in the arts and humanities

- have closer links with industry and commerce and promote enterprise.

But above all there is an urgent need, in the interests of the nation as a whole, and therefore of universities, polytechnics and colleges themselves, for higher education to take increasing account of the economic requirements of the country.

Meeting the needs of the economy is not the sole purpose of higher education nor can higher education alone achieve what is needed. But this aim, with its implications for the scale and quality of higher education, must be vigorously pursued. ...

The Government and its central funding agencies will do all they can to encourage and reward approaches by higher education institutions which bring them close to the world of business. . . (pp. 83-84)

The same principles were to be applied to research. Research councils were directed to give greater priority to targeted efforts that could yield better results with respect to commercial exploitation. Maclure (1988, pp. 87-88), in commenting on the British government's decision to replace the University Grants Committee by a University Funding Council (UFC) on which academics lost the majority that they had previously held, noted that the UFC would receive directions from the Secretary of State about terms and conditions under which payments were to be made to universities. As a result, more policies would be made centrally, more attention would be directed to performance indicators, and the role of civil servants would be enhanced.

A final assessment by Maclure (1988) warrants special emphasis:

It is difficult to exaggerate the magnitude of the change in the management of British higher education implicit in these sections of the Act. One set of long-standing conventions has been swept away. The 
foundations have shifted. The idea of universities as independent centres of learning and research, capable of standing out against government and society, and offering critical judgments of varying objectivity, informed by learning and protected by the autonomy of historic institutions, is discarded. Instead universities are made the servants of the State and its priorities. In the context of the late twentieth century they, like the rest of the education system, are to be used in the attempt to create a nation of enterprise and to discredit the 'dependency culture' associated with the forty years after World War Two. (p. 88)

Recent developments in Australia parallel those in Canada, the United Kingdom, and elsewhere. The following statements from the Australian federal government's document entitled Higher Education: A Policy Statement (Dawkins, 1988) clearly identify its desires:

The Government intends to shift a proportion of general infrastructure research funding to competitive research schemes, in line with its goal of maximizing the research potential of the higher education system and achieving a closer alignment with broader national objectives. (p. 83)

The Government supports the development of a funding system that responds to institutional performance and the achievement of mutually agreed goals. It intends to develop funding arrangements that take into account a range of output, quality and performance measures, and will initiate moves in this direction during the 1989-91 triennium. (p. 85)

The Government . . . expects that Commonwealth funding for research should be focused more effectively on those institutions and staff with a demonstrated capacity and record of research performance. (p. 92).

In England and Wales, Australia, New Zealand, and some American states, governments also have recently introduced measures to alter organizational arrangements substantially and to provide a greater market orientation in the school sector. This information is included in order to point out that, although the K-12 and postsecondary situations are not analogous, the reorganizational and market aspects are not restricted to the postsecondary sector. Of course, English independent schools have for many years provided prime examples of entrepreneurial activity in the $\mathrm{K}-12$ sector. In Great Britain, the movement toward devolution of authority in order to achieve what is called "school-site 
management" has been one of the attempts to foster competition among educational institutions. Tomlison (1989) concluded that "in 1988 the state [Britain] is ceding its responsibilities to the market place and it is legitimate to conclude that the long-term effect must be to widen the differences in opportunities" (p. 279). In support of the Bill that would ensure a market-led educational system and to explain the crucial nature of this system to the "health and wealth" of Great Britain, the Secretary of State was reported by Tomlison (1989) to have said that the new system is:

about enhancing the life chances of young people, about competition, choice and freedom, and about quality and standards. Additionally, it is about the devolution of authority and responsibility, and about harnessing the energies and commitment of teachers, parents and business people. (p. 276)

Further, Sexton (1987) suggested that:

the more that those customers, parents of children, have a direct relationship, preferably direct financial relationship, with the schools, the more that they can exert their "market" demands, and the more that free market will raise the quality of education-far more so than any dozens of government departments or any hundreds of local education authorities. (p. 9)

In New South Wales, Australia, similar opinions were expressed by the Management Review (1989) which conducted a comprehensive examination of the state education department. It concluded that the centralised and state-controlled educational system seriously impaired the ability of schools to respond to their local needs, that is, to "the market."

The loose and elusive input-output relationship in education, the mounting criticism over government inefficiency, the global economic recession, and a projected decline in enrolments appear to have provided some governments with the momentum to institute several radical changes. The challenges of the 1990 s, which are summed up in the terms "globalization of business" and "internationalization of education," have further justified the need to restructure educational systems (see, for example Naisbitt, 1990, and Tye, 1991). Also, the worldwide developments in technology add to these challenges. A shrinking world implies that "territorial walls" are crumbling; therefore, competition will be found where there was none before and intensified where it exists. (For example, Gonzaga University, located in Spokane, Washington, is offering graduate programs which extend to the northern part of Alberta, Canada.) 
Governments are increasingly concerned about the ability of their countries to compete in the global market. The Second Report of the House of Commons Standing Committee on Industry, Science, and Technology (Sparrow, 1990) stated that "education is central in meeting this challenge [of providing the education and training needed in jobs related to Canada's competitiveness]. From kindergarten through university, to job training and retraining, every aspect of our educational system must work to prepare Canadians for the future" (p. 2). While governments recognize the importance of education to achieve these objectives, there seems to be little or no faith in the present system to accomplish the task. The injection of competition into educational systems therefore is seen by many governments as a preparation for the 1990s and beyond.

Where politically feasible, governments have introduced varying degrees of privatization, that is, the transfer of assets and services in part or whole from the public to the private sector. This is seen by some governments to be a better alternative to public funding of public services. Fixler (1986) stated that "increasing reports of privatization in other nations indicate that it is a worldwide phenomenon. Developed and underdeveloped nations, and even some communist countries, are privatizing services and activities to one degree or another" (p. 1). With the mounting criticism of the quality and relevance of some aspects of education on the one hand, and the inefficiency of protected industries on the other hand, a logical reaction for many governments is to withdraw their responsibility for full funding of education. Policies that would enhance private participation in education whereby the public would have more say, institutions would be more accountable, and governments would have less financial burden, are becoming increasingly popular in many nations.

The initiatives described clearly demonstrate that the governments of several countries wish to restructure some aspects of the organization of educational institutions (both postsecondary and K-12) and the means by which they are funded in an attempt to ensure that they are more involved in helping to achieve national and provincial economic objectives. The directed nature of research grants and the desired restriction of research funding to institutions and individuals with demonstrated records of research effectiveness provide two of the most radical examples of direct intervention. The implications for greater emphasis on marketing and entrepreneurial activities are very clear. 


\section{Institutional Initiatives}

The notion of "public education in the marketplace" has gained in popularity among politicians, administrators, and even educators. Shatlock, Booth, Wagner, and Williams (1989) acknowledged that "it is impossible to deny the world-wide ideological currents which mean that most political leaders now consider fragmented individual choices by consumers to be preferable to centralized decisions by planners and producers" (p. 96). The public also wants greater transferability of academic credit for students who move among educational systems.

Belief in private competition as the most viable way to achieve creativity, innovations, quality, and cost-efficiency in education is not new. Adam Smith (cited in Friedman, 1975) argued over 200 years ago, that "those parts of education, it is observed, for the teaching of which there are no public institutions, are generally the best taught" (p. 272), and John Stuart Mill (cited in Garforth, 1980) stated about a century ago that

a general State education is a mere contrivance for moulding people to be exactly like one another: and the mould in which it casts them is that which pleases the predominant power in the government, whether this be a monarch, a priesthood, an aristocracy or the majority of the existing generation, in proportion as it is efficient and successful, it establishes a despotism over the mind, leading by natural tendency to one over the body. (p. 123)

Praise for the achievement of the market system in various sectors is growing. Friedman (1975) argued that "music or dance, secretarial skills, automobile driving, airplane piloting, technical skills-all are taught best when they are taught privately. Try talking French with someone who studied it in public schools, then with a Berlitz graduate" (p. 284). Some private higher educational institutions in the United States have become centres of excellence with international reputations.

In a shrinking world, competition is unavoidable, especially as corporate industries are increasingly offering educational services, perhaps more efficiently and effectively. Those who favour competition, therefore, argue that the injection of competition in educational systems is aimed at preparing higher educational institutions for the challenges of a shrinking world. Although an indisputable need exists for liberal education, any society that generally favours competition is more likely to move toward a market-led educational system. 
Bélanger (1989) made this relevant assessment:

All universities nowadays, of whatever size, find themselves in a competitive struggle, the consequences of which are beneficial for some and costly for others, depending on the mission they have selected for themselves and the leaders they have installed to pursue their particular paths of excellence. (p. 14)

This struggle also involves the search for corporate donations. Many universities envy Harvard's total endowment, identified by Footlick (1990) as "a stupefying $\$ 5$ billion" (p. 52), and few universities have any chance of approaching it. However, in 1988-90, the University of Toronto raised $\$ 125$ million, described as "the largest private fundraising effort in Canadian history," and the University of British Columbia raised \$66 million in 1989-90 ("Over the top," 1991). Some academics consider that chasing donations compromises their freedom, but Douglas Wright, President of the University of Waterloo, in an interview in the Bulletin of the Canadian Society for the Study of Higher Education (1990b), expressed the view that "universities would enhance their independence, rather than endanger losing it, by accepting more contributions from business and corporations. 'Independence comes out of pluralism. You lose independence if you have only one paymaster' " (p. 1). Raising money to assist with operating budgets can lead to an increase in financial autonomy. One implication of this for the internal management of postsecondary institutions, the Council of Europe (1990, p. 15) noted, is a concomitant growth in the direction of professionalism and market-orientation.

Another important initiative involves the matching by governments of funds raised from private sources. In 1991, Alberta and British Columbia were the only two provinces with post-secondary matching funds programs. Brief descriptions of Alberta's three matching initiatives in the 1980s, which are prime examples of this thrust, are provided below:

1. 1980s Endowment Fund: $\$ 80$ million government contribution; the original timetable was 1980-90, but funds were expended by 1985 .

2. Endowment and Incentive Fund 1: \$80 million government contribution for 1986-1994; overwhelming private sector support changed the parameters to $\$ 128$ million for 1986-1988.

3. Endowment and Incentive Fund 2: $\$ 80$ million government contribution for 1989-1999; more restrictions have been placed upon this fund, as identified in Note 1.

As of March 1992, these three programs had injected approximately $\$ 428$ 
million in new government and private funds into public postsecondary institutions in Alberta.

Probably the greatest manifestation of university entrepreneurial initiatives lies in the marketing of staff expertise, inventions, and discoveries. The move to foster the university/industry relationship, recommended by the Council of Europe (1990, p. 13), is geared toward "research for dollars"; hence, this type of research is, in many cases, applied and industry-specific. Academics often criticize this arrangement on the ground that it would cripple basic or curiositydriven research, which is equally important to the society. Because the results of industry-specific research cannot always be published freely, a cooperative approach may achieve one of the goals of a university, that is, to disseminate information. Fairweather (1988) observed that

The growth of alliances between business and higher education reflects the perception by government, industry, and academe that a significant overlap of interests exists. Academic institutions, for example, require additional resources. Industry is willing to provide resources in exchange for access to students, faculty, and resources. Only at the most general level (e.g., desire for an improved economy), however, can academe and industry be said to have identical interests; in most cases, institutions of higher education participate in alliances for reasons different from those of their industrial counterparts. (p. 23)

Gregor (1990) has provided the following assessments about this universityindustry relationship:

Efforts to foster research excellence at the provincial level appear increasingly to emphasize technological development.

At both levels of government there is also an increasing inclination to have appropriate ministries more active in entering into research partnerships with universities or other agencies.

Related university initiatives are to be seen in the increased number of institutional offices set up to facilitate co-operative ventures with business and industry; and in the establishment of research or technological parks in juxtaposition with university campuses . . and thus foster more effective collaboration.

The message has been conveyed that the postsecondary curriculum must take better cognizance of the country's place and future in a world community. (p. 962)

The importance being placed on this relationship is further demonstrated by 
the holding of a Business and Education Conference sponsored by The Conference Board of Canada (Toronto, 24-26 April 1991). Also, Weston (1991) reported that 14 university-related research parks are either currently planned or established in Canada, with the world total now being 175.

In order to provide a concrete example of university entrepreneurial activities, information is included here about the Intellectual Property and Contracts Office (IPCO) at the University of Alberta (1991). In a document which describes its operations, IPCO lists these benefits of technology transfer: "increased competitiveness in the international market place, economic diversification, creation of jobs, industries and companies, and increased funding opportunities through collaborative industrial research" (p. 1). The first Canadian technology-transfer office was established at the University of Toronto in 1981, while the majority were formed in 1985-86; most rely on both government and university funding (p. 1). In 1990, the University of Alberta's Office of Research Services was split into IPCO and the Research Grants Office in recognition of the growing importance of intellectual property transfer. IPCO has these three objectives:

1. To enhance and expand the research horizons of the University

2. To facilitate intellectual property transfer out of the University

3. To achieve financial recovery on intellectual property transfer (p. 3)

The Faculty Agreement between the University of Alberta (1988) and its Academic Staff Association includes this statement:

The University Patent Policy has the purpose of encouraging the staff to patent inventions and to provide a mechanism for the commercial application and utilization of the inventions while at the same time rewarding the inventor and protecting the rights of the University where the inventions were made using University facilities. (p. 72)

Inventors can either seek patent protection and commercial partners on their own initiative or offer the technology to the University which can then patent and commercialize the invention. The inventors and the University share the royalties in either case.

IPCO noted that "financial returns from University technologies most often come from licensing," but, because the University is in the early phase of writing such licences, royalty revenue has been minimal (p. 5). Individual faculty 
members also have been encouraged to start companies based on technologies that they have developed; examples are Chembiomed Ltd., Biomira Inc., and Synthetic Peptides Inc. The University benefits directly from equity interests in these companies and from royalties. Further, IPCO staff maintain close relationships with several government departments and crown corporations involved in technology transfer, e.g., the National Research Council, the Alberta Research Council, Science and Technology Canada, and Alberta Technology, Research and Telecommunications. The recent Report of the House of Commons (Sparrow, 1990) included this relevant statement: "The Committee recommends that the federal government facilitate technology transfer throughout the country by such means as a National Technology Information Network: enhanced technological personnel exchange among government, industry and the universities; government-industry sponsored technology centres; etc." (p. 11).

To recapitulate, universities themselves can act in entrepreneurial ways which are not necessarily triggered by government underfunding or restructuring. Of special significance in North American universities are many activities related to cooperative linkages with business, patents, inventions, and discoveries. Individual institutional initiatives also involve attracting students and funds, greater privatization, new programs, and greater coordination and cooperation.

\section{Discussion}

The thesis presented at the beginning of this paper, namely, that postsecondary institutions are becoming more entrepreneurial as a result of three complementary developments, is supported by the evidence provided. In many countries, one or more of the following, i.e. declining real revenue and rising costs, an increase in government influence upon restructuring, and an increase in institutional interest in entrepreneurialism, have been associated with an overall increase in entrepreneurial activities in postsecondary institutions. The stimuli for this increase and their relationships with the other variables discussed in this article are presented in Figure 1.

Some educational administrators have urged higher educational institutions to seize this opportunity to restructure rather than resist the changes of the 1980s and the 1990s. For example, Shapiro (cited in O'Brien and Siyahi, 1989) remarked that

if American higher education is to retain its vitality as a cultural institution, it will have to continue to adapt and change in a manner that both serves the society that supports it and remains constant to the sustaining traditions and values of higher education itself. To imagine that higher education institutions have reached their final 


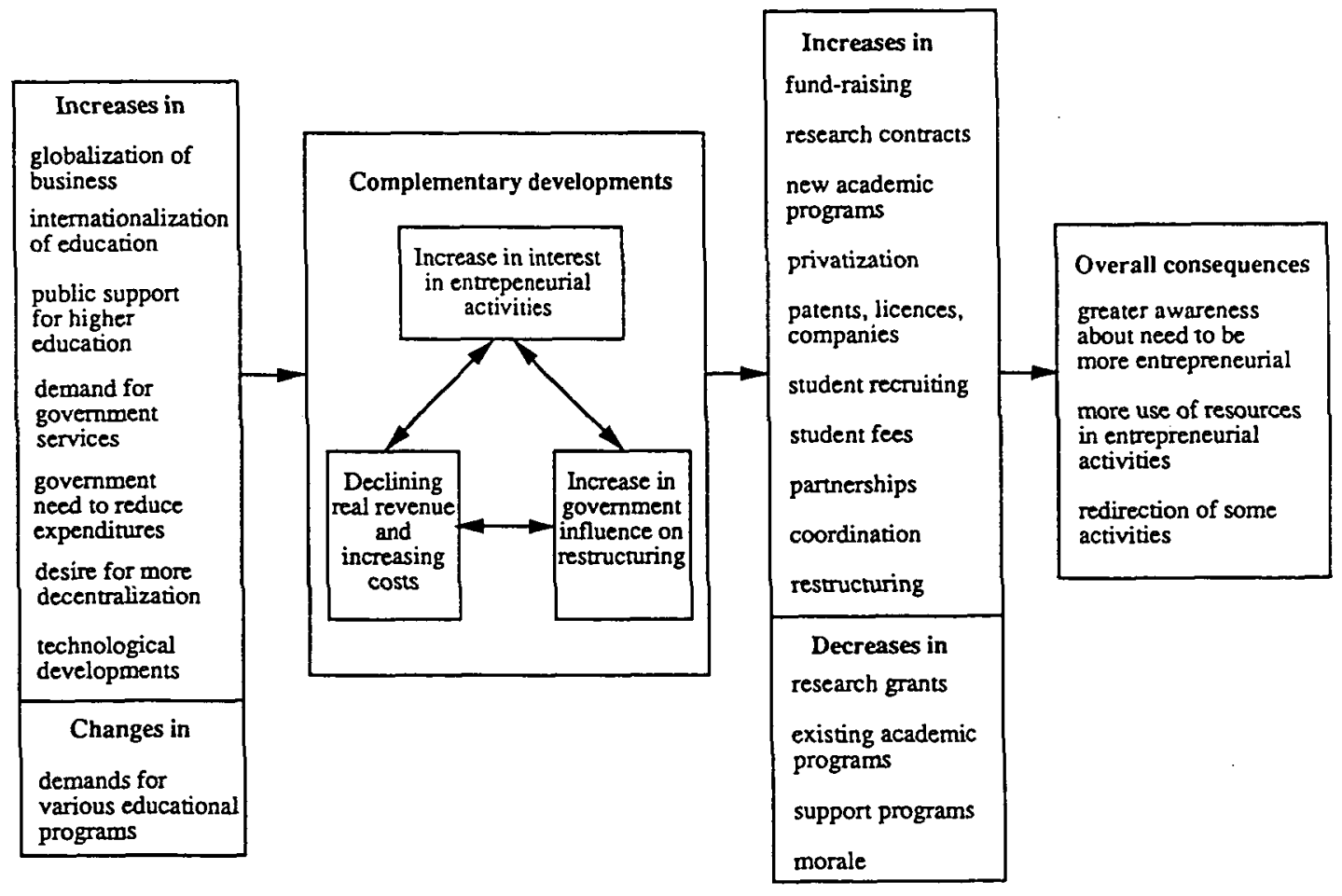

Figure 1. Stimuli for and effects of increasing entrepeneurialism 
and most perfect form would be a special intellectual arrogance indeed. (pp. 1-2)

Burgess (1982) has succinctly described the two major autonomous and service traditions of higher education. The autonomous tradition is "aloof, academic, conservative and exclusive"; education is seen as "an activity with its own values and purposes, affecting the rest of society obliquely and as a kind of bonus." The service tradition "explicitly expects education to serve individuals and society and defends it in these terms" (p. 70).

In its deliberations about the financing of higher education and research, the Council of Europe (1990) associated its activities with those of the Organization for Economic Co-operation and Development (OECD) which had drawn the following conclusions based on 12 in-depth national case studies:

The main finding of this report is the growing diversity of higher education and its funding mechanisms in most OECD countries. The university has too many missions for the means available and, by decreasing their contributions, governments are hoping that diversification of financial sources will become the solution to the problems they themselves have allowed to develop. (p. 14)

Further, Massy (1990) identified these six ways by which "the gap between long-run growth rates of revenue and expense" can be closed: (a) increasing investment return; (b) enhancing revenue from mainline academic activities; (c) improving the productivity of administrative and support activities; (d) obtaining revenue from non-traditional sources; (e) improving the productivity of academic functions; and (f) terminating selected academic programs. (p. 25)

These changes have major implications for many aspects of the operation of postsecondary institutions. Those implications that deal with administrative competence, allocation of resources, student orientation, and related matters are addressed below.

\section{Administrative Competence}

A market-led Canadian educational system would be a radical departure from the traditional system of education and would have far-reaching implications for everybody involved with higher educational institutions. For example, it would move some of the responsibility for determining the quality of education from institutions to students, employers, and the general public. These groups would have to know what constitutes quality and how to identify the differences among various higher educational institutions.

Also, a shift would be necessary from the traditional approach of appointing 
academics, who typically have little or no administrative training, to positions which have substantial administrative responsibility. Emery (1987) acknowledged that

academics have been trained to teach and research rather than to administer and invest. Yet, over recent years, the promotional path for an academic has meant less teaching and research and more administration, management and institutional planning. This is not the ideal recipe for the creation of a senior management expert in fund-raising, sales promotion, investment portfolios and the export of educational services. Nevertheless, institutional viability is now largely dependent upon selling additional services. (p. 84)

More training in personnel administration, finance/budgeting, organizational analysis, office management, and public relations would probably be necessary. In a competitive environment, educational leaders would be expected to be entrepreneurs and "intrapreneurs"-individuals who possess the skills necessary to ensure institutional survival and growth and who understand the business of education. In this regard, McWilliam (1990) observed that "the bureaucratic structure and functioning of colleges as a sub-set of a bureaucratic government prohibited refinement of organizational purposes. . . . Poorly executed communication and collaboration linkages ensured that innovative efforts went unlinked with opportunities for meaningful exploitation of them" (p. 93). This author further stated that "individuals bemoaned limited strategic planning, absence of a clear college mission, role, and mandate, lack of educational leadership, centralised decision-making and control, a 'pigeonholing structure,' lack of linkages between committees, polarised and competing factions, and incongruence between stated and enacted philosophy" (p. 95).

In a market-led educational system where leaders would be expected to act decisively and promptly, the planning and monitoring of changes within each institution would have to be much more centralized and more focused than they currently are.

\section{Allocation of Resources}

Traditionally, the allocation of resources within higher educational institutions has been based on program need. In many instances, program development and delivery reflect the interests of academics. Consequently, a program-based budgetary allocation may not necessarily reflect the demand or utility of such a program, at least from the point of view of the general public. Once programs are developed they become parts of a faculty's territory and must be protected, and 
the review of academic programs may have little relevance to societal need. Even where program reviews are carried out, the process and outcome often represent the views of the academics rather than the views of students, employers, and the general public. A greater customer orientation in conducting program reviews is probably warranted. In an article which both criticized many university practices and offered suggestions for effective strategies for the 1990s, Chaffee (1990) considered that service to "customers"-students, employers of graduates, research funding agencies, etc. - should be the guide for action even though many people in higher education are uncomfortable with the term "customers" (p. 61).

Under a market-led educational system, the allocation of resources would depend more on the needs of identifiable targeted groups and would be reflected through their demand for programs. When a particular program suffers low enrolment, the department concerned would be required to examine the reason. When low enrolment is related to lack of knowledge of the existence or importance of the program, a concerted effort to educate the public and popularise the program could be carried out. When the problem is obsolescence, a review to up-date or phase-out the program would be conducted. A general liberal education need not suffer under a market-led educational system if the benefits of such education are appropriately communicated to the relevant publics. To be able to respond to changes in the environment, a market-led system of higher education would require resources that would be more redeployable. In many places, a budgetary system has already been adopted to enable institutions to redeploy their resources to meet local needs.

\section{Student Orientation}

A greater emphasis on students would mean that attracting students, keeping them at the institution, and producing larger numbers of graduates, without sacrificing quality, would be central concerns of administrators. A different administrative approach towards students can become necessary because of changes that are occurring in the composition of the student body in postsecondary institutions. Some of these changes include declining percentages of the 18-24-yearold cohort, increasing participation of matriculated and non-matriculated adult students, and increasing percentages of part-time students and students with special needs, such as single parents and minority students (West, 1988). To meet the needs of such students, higher educational institutions should examine different aspects of administration, such as greater use of credit cards, increased library hours, reduced residency requirements, and more day-care facilities. 
Contrary to the common notion that market-led educational systems would concentrate institutional efforts on enrolments at the expense of academic standards, the long-term attraction possessed by an institution under this system would be its perceived quality of education. Different kinds of institutions for different kinds of people may result. Of course, special provisions for various disadvantaged groups would still be necessary.

\section{Other Issues}

Greater emphasis on university initiatives with respect to attracting students, donations and funds from non-traditional sources, privatization, research grants and contracts, patents and licences, coordination, and new programs raise several important issues which should be identified before particular initiatives are discussed:

- what should be the relative contributions of governments, "users," and alumni to the cost of postsecondary education?

- to what extent is education a "public good" or a "private good'?

- where should university activities focus on development of students and the development of the economy?

- where should university research activities be located on the basic-applied continuum?

- to what extent does the "search for dollars" interfere with teaching, research, and service?

University initiatives with respect to raising instructional fees need to be examined to ascertain whether they restrict access. Free education does not necessarily result in equal participation among the various social and economic classes within a society. Granting that there is some correlation between educational cost and accessibility, the purpose of a social welfare program in a capitalist state is to assist the less advantaged people to gain access to equitable participation, health, food, and education. Governments can therefore be more relevant to society by assisting the less advantaged to gain access to these services. Some advocates of the voucher system, such as Friedman (1975), argued that, contrary to the common notion, a voucher system of education would indeed increase the participation rate of the less advantaged and minority groups. A market-led educational system is possible without the government abdicating its educational responsibility - which is to ensure that every person has access to educational services. Perhaps the most common criticism is the effect of a 
market-led educational system on accessibility. Some fear that higher educational institutions would charge exorbitant fees and thus exclude the less advantaged but equally competent students. With respect to fees and accessibility, the Bulletin of the Canadian Society for the Study of Higher Education (1990a) reported that "research, however, has shown little or no correlation between low fees and student enrolment" (p. 1). The Society also noted that various countries that have experimented with zero fees have met with limited success; for example, "Swedish universities charge no tuition fees, and have found that students from less affluent homes still enrol in shorter programs than students from wealthier backgrounds" (p. 1).

\section{Conclusions}

Many current moves are characterized by increasing emphasis on competition, self-reliance, and responsiveness. Several advantages of a market-led educational system are laudable, but equally convincing are some of the arguments against the system. The possibility of increasing inequality in society is paramount among the arguments against a market-led education system. Some researchers have responded to this by indicating that there is little or no correlation between the level of student fees and the extent to which eligible citizens enrol.

The major implication or conclusion to be drawn from this debate appears to be the need for balance between conflicting forces and demands. Katz (1986) reminded us that "the conflict between the forces of the marketplace and of the community in higher education echoes an old struggle" (p. 6). Also, Massy (1990) cautioned that "common sense and sensitivity to the world around us are as important to achieving our objectives as intellectual prowess" (p. 27). Postsecondary institutions need to be more responsive (i.e., more entrepreneurial, more market-oriented) to a variety of societal needs, while still maintaining academic standards, values, and relevant traditions.

Finally, we must recognize that adoption of more entrepreneurial activities in higher educational institutions will have consequences for their administration. Special attention will need to be directed towards institutional missions, communication channels, coordination of activities, criteria used in personnel decisions, and informing the public about the importance and contributions to society of postsecondary institutions. Although the balance between the 
marketplace and academic concerns must always be preserved, perhaps the time has now come to recognize that the fulcrum has moved, and may continue to move, somewhat towards the marketplace. Greater emphasis on entrepreneurialism in higher education may well prove to have more advantages than disadvantages.

\section{Notes}

1. Alberta Advanced Education provided the following additional information about its Endowment and Incentive Fund 2:

The major difference between this program and its two predecessors is the establishment of maximum institutional allocations to ensure the full life of the program. The institutions are responsible for establishing their priorities within their annual allocations and making the appropriate matching grant applications. Cash gifts for endowments, operating expenses and capital purposes can be matched on a 1:1 basis and gifts of books and equipment for teaching or research purposes can be matched up to an amount that does not exceed the value of the books or equipment, as determined by the Minister of Advanced Education.

Also, private donations to universities were not eligible for matching grants after 1 April 1992, except those provided for capital projects of an exceptional nature.

2. The assistance provided in the preparation of this article by Michael Andrews, Marc Arnal, Ronald Boivin, Joe Fris, Bing Mah, David Norwood, Janice Park, and Eva Radford is gratefully acknowledged. The authors also wish to recognize the valuable comments provided by reviewers of an earlier draft of the article.

\section{References}

Alberta Advanced Education. (1989). Goals and priorities: Post-secondary education 1989 to the year 2000. Edmonton, AB: Author.

Alberta Advanced Education. (1989). Guidelines for system development. Edmonton, AB: Author.

Association for Supervision and Curriculum Development. (1990). ASCD issues analysis: Public schools of choice. Alexandria, VA: Author.

Axelrod, P. (1986). Service or captivity? Business-university relations in the twentieth century. In W. A. W. Neilson, \& C. Gaffield (Eds.), Universities in crisis: A mediaeval institution in the twenty-first century (pp. 45-68). Montréal, Que.: The Institute for Research on Public Policy.

Bélanger, C. H. (1989). University entrepreneurship and competition: The case of the small universities. The Canadian Journal of Higher Education, 19 (2), 13-22. 
Burgess, T. (1982). Autonomous and service traditions. In L. Wagner (Ed.), Agenda for institutional change in higher education (pp. 70-79). Guilford, Surrey, U.K.: The Society for Research into Higher Education.

Burrup, P. E., \& Brimley, V. (1982). Financing education in a climate of change (3rd ed.). Boston, MA: Allyn \& Bacon.

Canadian Society for the Study of Higher Education. (1991). Commission boss fears universities changing too slowly. Bulletin, (Winter), 2.

Canadian Society for the Study of Higher Education. (1990a). Universities struggle with cost of tuition for higher education. Bulletin, (Winter), 1-2.

Canadian Society for the Study of Higher Education. (1990b). University of Waterloo head to set panel on education. Bulletin, (Spring), 1.

Carter, C. (1980). Higher education for the future. Oxford, UK: Basil Blackwell.

Chaffee, E. E. (1990). Strategies for the 1990s. New Directions for Higher Education, No. 70 (Summer). San Francisco, CA: Jossey-Bass.

Cooper, B. S. (1988). School reform in the 1980s: The new right's legacy. Educational Administration Quarterly, 24 (3), 282-298.

Council of Europe. (1990). Financing higher education and research-Resolution 945 of the Parliamentary Assembly, adopted 11 May 1990. Educational Newsletter, 4/90. Strasbourg, France: Author.

Dawkins, J. S. (1988). Higher education: A policy statement. Canberra, Australia: Australian Government Printing Service.

Decore, A. M., \& Pannu, R. S. (1989). Alberta political economy in crisis: Whither education? Canadian Journal of Education, 14 (2), 150-169.

Dennison, W. F. (1990). Performance indicators and consumer choice. International Journal of Educational Management, 4 (1), 8-11.

Emery, J. S. (1987). Education and enterprise. UNICORN: Bulletin of the Australian College of Education, 13 (2), 83-88.

Fairweather, J. S. (1988). Entrepreneurship and higher education: Lessons for colleges, universities, and industry. Washington, D.C.: ERIC Clearinghouse on Higher Education.

Fixler, P. E. (1986). Privatization 1986. Annual report on privatization of government services. Santa Monica, CA: Reason Foundation.

Footlick, J. K. (1990, June 11). Giving Harvard notice. Newsweek, pp. 52, 54.

Friedman, M. (1975). An economist's protest.. Glen Ridge, NJ: Thomas Hoctor.

Garforth, F. W. (1980). Educative democracy: John Stuart Mill on education in society. Oxford: Oxford University Press.

Gregor, A. D. (1990). The universities of Canada. Commonwealth Universities Yearbook 1990 (pp. 955-968). London: The Association of Commonwealth Universities.

Hogbin, G. (1987). Privatizing the consumption of education. In P. Abelson (Ed.), Privatization: An Australian perspective (pp. 227-248). Sydney, Australia: Australian Professional Publications. 
Katz, M. B. (1986). The moral crisis of the university, or, the tension between marketplace and community in higher leaming. In W. A. W. Neilson, \& C. Gaffield (Eds.), Universities in crisis: A mediaeval institution in the twenty-first century (pp. 3-27). Montréal, QC: The Institute for Research on Public Policy.

Kogan, M. (1988). Normative models of accountability. In R. Glatter, M. Preedy, C. Riches, \& M. Masterton (Eds.), Understanding school management (pp. 139-153). Philadelphia, PA: Open University.

Kotler, P. \& Fox, K. F. A. (1985). Strategic marketing for noneducational institutions, (3rd ed.). Englewood Cliffs, NJ: Prentice-Hall.

Maclure, S. (1988). Education re-formed. Sevenoaks, Kent, UK: Hodder \& Stoughton.

Management Review. (1989). Schools renewal: A strategy to revitalise schools in the New South Wales state education system. Milsons Point: NSW, Australia: NSW Education Portfolio.

Massy, W. F. (1990). A paradigm for research on higher education. In J. C. Smart (Ed.), Higher education: Handbook of theory and research: Vol. 6 (pp. 1-34). New York: Agathon.

Maynard, A. (1982). Privatization and market mechanisms. In A. Morris \& J. C. Sizer (Eds.), Resources and higher education (pp. 58-80). Guildford, Surrey, UK: Society for Research into Higher Education.

McWilliam, C. L. (1990). Innovation and entrepreneurship in colleges: An interpretive study of the piloting of innovation centres. The Canadian Journal of Higher Education, 20 (3), 85-102.

Naisbitt, J. (1990). Global education. Inside Guide, 4 (3), 8-9.

O'Brien, P., \& Siyahi, C. (1989, November). Challenging old standards: Strategy and planning for a new metropolitan model. Paper presented at the American Marketing Association National Symposium for the Marketing of Higher Education, Cincinnati, $\mathrm{OH}$.

Over the top. (1991, February). University Affairs, 32 (2), 19.

Perot, H. R. (1989). Educating our children for the next century. Educom Review, 24 (1), 14-17.

Ribich, T. I. (1970). The effect of educational spending on poverty reduction. In R. L. Johns, (Ed.), Economic factors affecting the financing of education (pp. 207-234). Gainsville, FL: National Educational Finance Project.

Sexton, S. (1987). Our schools. In S. Sexton (Ed.), The funding and management of education (pp. 5-12). Warlingham, Surrey, UK: Institute of Economic Affairs, Education Unit.

Shapiro, H. T. (1986, May). American higher education: A special tradition faces a special challenge. Occasional Paper (16). Paper presented at the Annual Dinner of the Academy for Educational Development, New York.

Shatlock, M., Booth, C., Wagner, L., \& Williams, G. (1989). Editorial. Higher Educational Quarterly, 43 (2), 95-188. 
Sparrow, B. J. (1990). Canada must compete. Second Report of the Standing Committee on Industry, Science and Technology, Regional and Northern Development. Presented to the House of Commons, Ottawa, ON: Queen's Printer.

Tausig, C. (1991). Recent poll reveals majority support increased university funding. University Affairs, 32 (3), 48.

Tomlison, J. (1989). The education reform bill- 44 years of progress? Education Policy, 4 (3), 275-279.

Tye, K. A. (Ed.) (1991). Global education: From thought to action. Alexandria, VA: Association for Supervision and Curriculum Development.

University of Alberta. (1991). University technology transfer. Unpublished paper. Edmonton, AB: Intellectual Property and Contracts Office.

Weston, J. (1991, January). University Affairs, 32 (1), 10.

West, E. G. (1988). Higher education in Canada. Vancouver, BC: The Fraser Institute. 